\title{
Er det trygt å føde hjemme?
}

I en stor amerikansk studie var planlagt hjemmefødsel assosiert med flere perinatale dødsfall enn planlagt sykehusfødsel.

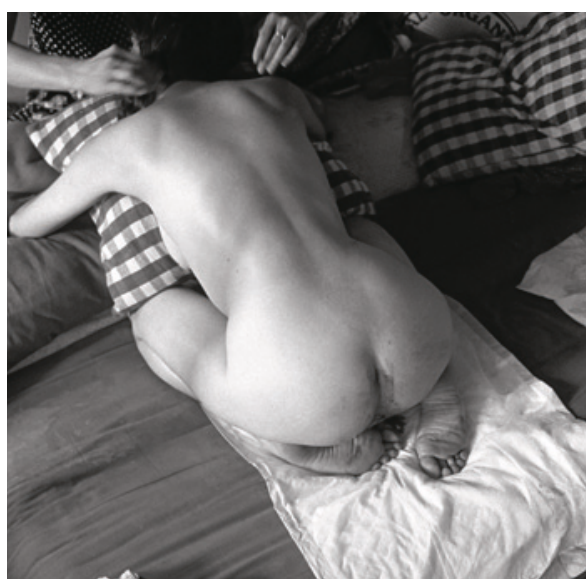

Illustrasjonsfoto: Cheryl Hatch/Corbis
Alle fødsler i Oregon i 2012-13, til sammen nærmere 80000 fødsler, inngikk i en retrospektiv studie der man studerte om hjemmefødsel versus sykehusfødsel påvirket forløsningsmetode eller sykdom og dødelighet hos mor og barn (1). Fødsler som var planlagt som hjemmefødsel, men der den fødende ble overført til sykehus underveis i fødselen ble regnet med som hjemmefødsel.

Planlagt hjemmefødsel var assosiert med høyere perinatal dødsrate enn planlagt sykehusfødsel (3,9 vs. 1,8 dødsfall per 1000 fødsler, $95 \%$ KI 1,37-4,30). Hjemmefødsel ga høyere odds for lav apgarskår og kramper, men lavere odds for indusert fødsel, instrumentell forløsning og keisersnitt.

- Denne studien illustrerer hvorfor prinsippet om behandlingsintensjon (intentionto-treat) er så viktig, sier Ellen Blix, professor ved Høgskolen i Oslo og Akershus. En svakhet ved noen tidligere studier har vært at fødsler som har vært planlagt som hjemmefødsel, men som underveis er blitt konver- tert til sykehusfødsel, er blitt regnet som sykehusfødsel. Det ga skjevheter i resultatene.

Blix forteller at $\mathrm{i}$ en norsk studie med lignende design var det færre inngrep og komplikasjoner hos de hjemmefødende, men at studien omfattet for få fødsler til at man kunne trekke konklusjoner om dødelighet (2).

\section{Martine Rostadmo}

Tidsskriftet

\section{Litteratur}

1. Snowden JM, Tilden EL, Snyder J et al. Planned out-of-hospital birth and birth outcomes. N Engl J Med 2015; 373: 2642-53.

2. Blix E, Huitfeldt AS, Øian P et al. Outcomes of planned home births and planned hospital births in low-risk women in Norway between 1990 and 2007: a retrospective cohort study. Sex Reprod Healthc 2012; 3: 147-53.

\section{Plutselig, uventet hjertestans}

\section{Over 2500 personer får plutselig og uventet hjertestans årlig i Norge. Mange har symptomer i forkant, men unnlater å ringe nødnummer.}

I en amerikansk studie ble flere enn 800 voksne pasienter under 65 år eller deres pårørende intervjuet etter en plutselig uventet hjertestans (1). Informasjon ble også hentet inn fra journalene. Målet var å se hvilke symptomer pasientene hadde de siste fire ukene før uventet hjertestans og om tidlig kontakt med nødnummer kunne øke sjansene for overlevelse.

Halvparten av pasientene hadde hatt symptomer. Av disse hadde to av tre brystsmerter og/eller tungpustethet. Hos $93 \%$ forekom symptomene minst én gang det siste døgnet før hjertestans. Kun 19\% hadde ringt et nødnummer. Overlevelsen var på $32,1 \%$ (95\% KI 21,8-42,4 hos dem som ringte nødnummer ved symptomer, mot $6,0 \%(95 \% \mathrm{KI} 3,5-6,5)$ hos dem som ikke hadde ringt $(\mathrm{p}<0,001)$.

- Denne observasjonsstudien av pasienter med hjertestans viser som ventet mye lavere overlevelse hos pasienter som tar kontakt med nødnummer ved stans, enn ved symptomer før stans inntreffer, sier Petter Andreas Steen, professor emeritus ved Oslo universitetssykehus. - Dette er en relevant problemstilling også i Norge, sier han.

- Studien har en del svakheter. Hos $24 \%$ av pasientene med hjertestans manglet det data om mulige symptomer, og studien lider av seleksjonsskjevhet både hva gjelder hukommelse og rapportering. Likevel underbygger studien at rask reaksjon på symptomer på akutt koronarlidelse er viktig, sier Steen.

\section{Kaveh Rashidi}

Tidsskriftet

\section{Litteratur}

1. Marijon E, Uy-Evanado A, Dumas F et al. Warning symptoms are associated with survival from sudden cardiac arrest. Ann Intern Med 2016; 164 : 23-9.

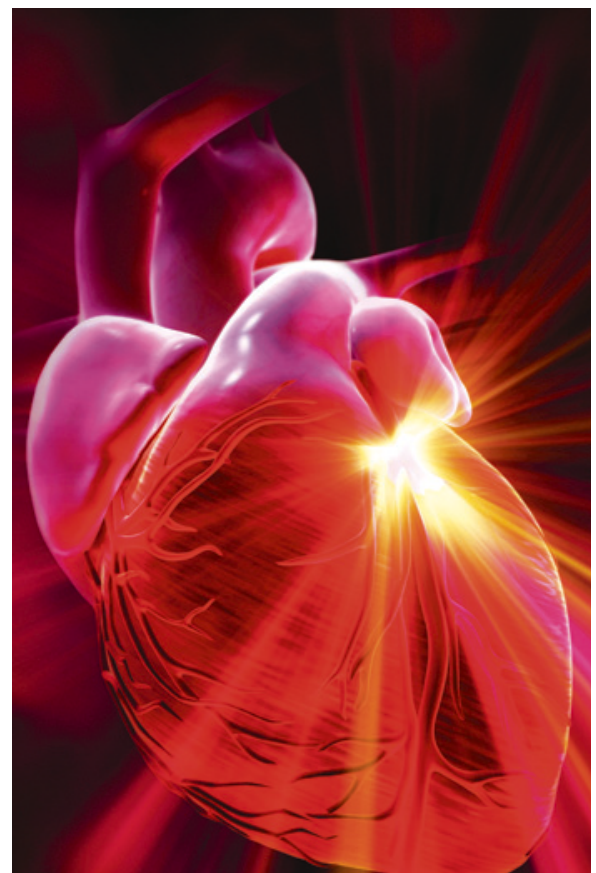

Illustrasjonsfoto: Science Photo Library 